is unlawful and if the girl is under 13 years it is punishable by life imprisonment. The girl can not consent to intercourse, however, if the man is under 24 years old, has not been previously charged with this offence or an attempt to commit this offence and he has reasonable cause to believe the girl is over 16 years old then he will not be guilty of an offence.

\section{Indecent assault}

In respect of indecent assault, boys and girls below the age of puberty ${ }^{16}$ are not deemed capable of consenting to acts which, without consent, would amount to indecent assault. This applies to heterosexual acts; for homosexual acts the age of consent is 16 years.

\section{Indecency involving children}

In Scots law it is a common law offence to behave in a lewd, indecent and libidinous manner towards children under the age of puberty. ${ }^{17}$ There is no defence of consent to this crime. If a boy or girl is over the age of puberty and they consent to heterosexual acts then there is no offence unless the actions fall within the offence of 'shameless indecency'. ${ }^{18}$ Under section 6 of the Criminal Law (Consolidation) (Scotland) Act 1995 it is a statutory offence to commit lewd practices towards a girl aged between 12 and 16 years. The girl's consent to such practices is irrelevant.

The relevant English law provisions prohibit acts of gross indecency ${ }^{19}$ with or towards children less than 16 years of age and make it an offence to incite a child to commit an act with him or another. ${ }^{20}$ This offence is necessary as an invitation to perform or participate in indecent acts is not an indecent assault under English law unless it is accompanied by force or threat of immediate force.

\section{Indecent exposure}

There is no separate crime of indecent exposure in Scots law. This act can be committed by a man or a woman and would be prosecuted as breach of the peace or a form of lewd practice. There is a statutory offence of indecent exposure in England and this prohibits a man exposing his penis in public or private with the intent to insult a female. ${ }^{21}$ The crime is, therefore, gender specific; however, indecent exposure by a man or a woman can constitute the common law offence of public nuisance or outraging public decency.

\section{Incest}

In Scotland incest is heterosexual intercourse between a child under the age of 16 years and his/her parent, sibling, grandparent, aunt/uncle, great grandparent, adoptive or former adoptive parent and by a person who is a member of the same household and is in a position of trust. The prohibitions also relate to relationships of half-blood. The crime of incest only relates to heterosexual intercourse and consequently homosexual acts and other forms of sexual misconduct are excluded. In English law incest relates to heterosexual intercourse between a man and his mother, daughter, sister or grand-daughter and between a woman and her grandfather, father, brother or son. ${ }^{22}$ Consent does not operate as a defence to a charge of incest and where consent is not present the crime of rape has been committed.

Statements on funding and competing interests

Funding. None declared.

Competing interests. None declared.

Clare Connelly, MA, LLB

Senior Lecturer in Law, School of Law, University of Glasgow, 8 Professor Square, Glasgow G12 8QQ, UK. Tel: +44 (0) 141330 4556. Fax: +44 (0) 141330 4900. E-mail: c.connelly@law.gla.ac.uk

Notes

See Hall R (1985) Ask any woman (Bristol: FallingWall Press); Chambers G, Millar A (1987) 'Proving sexual assault: prosecuting the offender or persecuting the victim' in Carlen $P$, Worrall A, Gender, crime and justice (Milton Keynes: Open University); Tempkin J (1987) Rape and the legal process (London: Sweet \& Maxwell); Brown B, Burman M, Jamieson L (1993) Sex crimes on trial (Edinburgh: Edinburgh University Press).

2 Hall R (1985) Ask any woman (Bristol: FallingWall Press). A total of 1236 women completed an extensive questionnaire on their experience of rape and sexual assault. More than one in six of the women had been raped (17\%), almost one in three had been sexually assaulted and one in five had survived attempted rape. Only $36 \%$ of women reported being raped by a stranger or strangers. One in five of the respondents reported having been raped or sexually assaulted as children or teenagers.

This change in definition was a result of a decision by the appeal court, Lord Advocate's Reference No. 1 of 2002 v Watt (22 March 2002), unreported at the time of writing. Most of the substantive criminal law in Scotland is common law and therefore changes in the law are the substantive criminal law in Scotlan
made by judges rather then Parliament.

made by judges rather then Parliam
'Defendant' in England and Wales.

Rape is a common law crime in Scotland. The definition can be found in Lord Advocate's Reference No. 1 of 2002 v Watt (22 March 2002), unreported at the time of writing.

6 Rape in England and Wales is a statutory offence contained within s.1 (1) of the Sexual Offences Act 1956 as substituted by the Criminal Justice and Public Order Act 1994, s. 142. Indecent assault is a form of aggravated assault. In Scotland this involves an intentional attack (interpreted very broadly and could involve touching) upon the person of another in circupto and 15 of the Sexual Offences Act 1956. Any touching in circumstances of indecency or a prehension of being touched in such circumstances will be indecent assault.

This is 10 years in England and Wales and 8 years in Scotland, although the latter is under This is
review.

review.
In respect of rape if an accused honestly believes that the woman is consenting to intercourse he can not be guilty of rape. There needs to be an honest belief in consent but it is not required to be a reasonable belief. This departs from the usual standard adopted in Scottish criminal law where an objective test of reasonableness requires to be fulfilled. The relevant case in England and Wales is DPP v Morgan [1976] AC 182 and in Scotland Meek v H. M. Advocate 1983 S.L.T. 280.

10 Chambers G, Millar A (1987) 'Proving sexual assault: prosecuting the offender or persecuting the victim' in Carlen P, Worrall A, Gender, crime and justice (Milton Keynes: Open the victim' in Carlen P, Worall A, Gender, crime and justice (Milton Keynes: Open Brown B, Burman M, Jamieson L (1993) Sex crimes on trial (Edinburgh: Edinburgh University Press).

11 See, for example, Cannon v H. M. Advocate 1992 S.L.T. 709, where evidence of a complainer's distress exhibited some 12 hours after a rape was held to be corroborative when there was evidence that she had delayed disclosing her distress until she had the opportunity to speak to a close friend.

2 S. 32 (1) (b) Criminal Justice and Public Order Act 1994.

3 S. 5 Criminal Law (Consolidation) (Scotland) Act 1995.

4 S. 5 (5) Criminal Law (Consolidation) (Scotland) Act 1995.

1992 S.L.T. 991

6 Puberty is determined to be age 12 years for girls and 14 years for boys.

17 'Lewd indecent and libidinous practices and behaviour' may take the form of indecent handling of the child by the accused or inducing the child to indecently handle the accused. There is no need for actual contact between the parties and the offence would include indecent There is no need for actual contact be

18 'Shameless indecency' is a very broad crime and has been held to include indecent exposure, selling obscene literature and showing a pornographic film in private.

19 Gross indecency is deemed to be limited to activities involving the genitalia, including contact through clothing.

20 s. 1 (1) of the Indecency with Children Act 1960 as amended by s. 39 of the Criminal Justice and Court Services Act 2000

S. 4 of the Vagrancy Act 1824

22 The Scottish provisions were consolidated by the Incest and Related Offences (Scotland) Act 1986. The relevant provisions are now found in Criminal Law (Consolidation) (Scotland) Act 1995 (ss. 1-4). The English provisions are found in the 1956 Sexual Offences Act.

\title{
Rape: The victim's perspective
}

\section{What is rape?}

Rape laws originally came from the Roman law of 'raptus'. Raptus was a violent theft that could apply to any kind of property belonging to a man, including his wife or children. From the beginning, rape laws have been designed to protect a man's property, not to protect women. This is why, until 1992, a husband could not be prosecuted for raping his wife. A man could not be charged for taking what was legally his.

The modern definition of rape is that a man commits rape 
if: (a) he has unlawful sexual intercourse, whether vaginal or anal, with a person who at the time does not consent to it and (b) at that time he knows that they do not consent or he is reckless as to whether they consent to it. Being 'reckless' means there is an obvious risk that the woman was not consenting and the man ignored this. The prosecution must prove that: (a) the person did not consent and (b) the man knew the person did not consent. It is only rape if there is penetration by the penis. Other acts (including oral sex) are classified as 'indecent assault'.

Between 1977 and 1996, the number of women reporting rape rose by $500 \%$, yet the number of convictions remained almost static. This means that in 1977 one in three women saw their rapists convicted, whereas in 1996 less than one in ten did. The current criminal justice system appears to be failing women. It sends out a message that rape is a lowrisk, high-reward activity. Statistics also indicate that at least $75 \%$ of all rapes go unreported.

\section{Reporting the rape}

Every woman needs to make her own decision about reporting a rape or sexual assault and it is important that she feels supported when she does make the decision. Police training has improved tremendously over the last few years, but it is not easy to go to a police station to report an assault or rape. If the victim does decide to report the rape, it should ideally be done as soon as possible and without washing or changing her clothes. However, all is not lost if the assault is not reported at an early stage because improved DNA techniques means that forensic evidence can be recovered from unwashed items of clothing many weeks, months or even years after the attack.

The victim will need a lot of support when reporting a rape to the police and may well wish to take a friend with her. Rape crisis centres provide a safer way of reporting if the victim is unable to face the prospect of going directly to the police. Although not every area has such a centre, there are confidential helplines to give support or advice. Another option is to contact the local Victim Support organisation. Alternatively, the victim may wish to approach someone who she feels she can trust such as her family doctor or other health professional. Many victims are afraid to tell anyone and these may be quite reasonable fears since even close friends may withdraw from her because they are not sure how to react; others may become overprotective.

Once the rape has been reported and the police are involved, a specially trained police officer is appointed to be a 'chaperone' to the victim. They will explain the procedures that need to be gone through. Most police stations now have a rape suite and the victim will be taken there. At some stage, if the rape is reported early enough, the victim will need to be examined by a doctor, and if she requires medical treatment, the doctor will arrange for treatment at a hospital.

The victim will be required to give a detailed statement to the police and this can be a very traumatic experience in itself. Before she signs the statement, she should read it thoroughly and make any alterations necessary. The statement is not confidential and will be released to the defendant as well as being used in court. She will not be allowed to keep a copy of her own statement and will not see it again until the case comes to trial, so it is essential that it is as accurate as possible when it is given to the police.

The average survivor may not realise that the criminal case is not her case. It is the Crown's case because rape, like other criminal charges, is a crime against the Crown. Whilst she is a very important witness, the survivor is exactly that: a witness. The prosecuting solicitor and barrister are not her representatives but represent the interests of the Crown. Often, the victim will not even meet these individuals until the day of the trial. Should a conflict arise, the interests of the Crown come before the interests of the victim. The victim has no rights in the decision-making process and this can be very painful and disempowering. Even if expert witnesses are involved by the Crown Prosecution Service (CPS) to assist with the prosecution, the victim is not told the content of their reports. Conversely, the defendant will get to see all the evidence. One important thing to remember is that once the rape has been reported to the police, the victim is granted lifetime anonymity and can never be named by the media unless she makes a conscious decision to publicise her case. The case can be reported, but she can never be identified.

\section{The court procedure}

The first formal stage is the committal hearing. This occurs once the rape has been reported to the police and it has been decided that sufficient evidence exists to arrest the defendant. The attacker is brought before a magistrates' court where it is decided if there is sufficient evidence for the case to go forward to the crown court for a full trial. The victim is not normally required to attend the magistrates' court, but she should be prepared for several adjournments or delays at this stage, which can be frustrating and stressful.

If it is decided that the case should go to crown court, then there will be a number of pre-trial hearings that are purely administrative in nature and will not require the victim to attend. During this stage the date for the trial will be decided. It would normally be about 6 months after the committal to crown court, but even this date is not fixed and may be adjourned at the last minute. The various individuals working for the CPS or the police are used to seeing this happen and almost take it for granted, but these delays can have a devastating impact on the victim.

The crown court can seem intimidating and confusing, but the Witness Support Service will provide a volunteer who can be with the victim to explain the procedures. They also arrange for the victim to visit the court a few weeks before the trial starts so that she can see the layout of the court and see where the witness box is in relation to where the judge/jury/barristers and defendant will be. With rape cases, they are often able to ensure some privacy within the court building so that there is no risk of the victim accidentally seeing the defendant outside the courtroom.

If the defendant pleads guilty, then she will not need to give evidence as it will simply be up to the judge to pass sentence. If he pleads 'not guilty' then plea-bargaining may take place. The defendant may be asked if he will plead guilty to a lesser offence, e.g. sexual assault rather than rape. This would guarantee a conviction and the victim would not have to give evidence, but the punishment would be less severe.

Assuming that he continues to plead 'not guilty' and no plea-bargaining is entered into, the trial will proceed. At some point during the trial, the judge will make a 'corroboration warning' which seems to make it harder to convict the attacker. The judge directs the jury not to convict unless there is evidence or witnesses to support the victim's version of events. The prosecution barrister will then outline the case against the defendant and witnesses will be called to support their case. The victim is not allowed to be in court prior to giving evidence.

The victim is usually the main prosecution witness and will be called to give evidence first. The prosecution 
barrister will take her through her detailed statement and then the defence barrister is allowed to ask questions (crossexamine) with the aim of discrediting the victim's account. The questioning will be rigorous but it is important that the victim does not allow herself to feel pressurised. If she does not understand a question, she should ask the barrister to explain it more clearly and should not be afraid to think carefully before answering it.

Once she has given evidence, the victim may sit in the public gallery and watch the rest of the trial. However, if she shows any emotion then it can be argued that she is influencing the jury and the judge would ask her to leave the courtroom for the rest of the trial. She should also bear in mind that relatives of the defendant could be in the public gallery.

After the barristers have finished presenting their evidence, the judge will sum up the case and the jury will be sent to a separate room to consider their verdict. If the defendant is found guilty, then the judge will set what he considers to be an appropriate sentence.

\section{Psychological impact on the victim}

For most women, rape is one of the most serious life crises they will have to face. They have probably never felt the extreme and overwhelming emotions before - the fear, the rage, the panic attacks or the worthlessness. There is no such thing as a 'normal' reaction to rape.

Fear is a pretty universal response to rape, but the things feared might be different for different women. It could be the fear of accidentally seeing the rapist again or fear of situations that remind them of the rape. They may associate places, sounds and smells with danger. The fear may be more generalised because of a loss of an inner sense of security.

The victim may feel discouraged and depressed about the future as if there is nothing to look forward to. Feelings of guilt, worthlessness or self-disgust may result. Decisions about even small, day-to-day matters may seem impossible, and there may be an overwhelming sense of exhaustion that makes concentration difficult. The depression can vary from day to day in its intensity and may also be associated with intense anxiety or agitation.

Rape victims may experience a significant, immediate loss of self-esteem that could last for a long time. The events that occurred and the memory of them are so degrading that the victim will feel humiliation and shame, and fear rejection by others who know the terrible acts she was forced to endure.

It is increasingly recognised that rape victims may suffer from post-traumatic stress disorder (PTSD). The diagnosis is now frequently made in reference to those crime victims whose distressing symptoms persist for an extended period of time after a traumatic event. It is a normal reaction seen in normal people who have been through a terrifying situation that they had no control over. According to the psychiatric diagnostic manual, DSM-IV, the following are some of the criteria that need to be met:

- The person must have been exposed to a traumatic event involving actual or threatened injury or death, during which they responded with panic, horror and feelings of helplessness.

- They re-experience the trauma in the form of dreams, flashbacks, intrusive memories or unrest at being in situations that remind them of the original trauma.

- They show evidence of avoidance behaviour.

- They experience physiological hyperarousal as evidenced by insomnia, agitation, irritability or outbursts of rage.

PTSD can be either acute or delayed-onset in nature. Acute PTSD occurs within 6 months of a traumatic event. In delayed-onset PTSD the symptoms occur after 6 months and it has been known to occur as long as 20 or even 40 years after the traumatic event. It is not incurable, but any intervention should be swift and appropriate. The wrong therapist can do more harm than good, and effective therapists should do the following:

- See the trauma as real and important in itself, apart from any pre-existing psychological problems.

- View the victim as being a survivor capable of being healed - not as a hopeless psychiatric case.

- Educate the victim about the nature of trauma and the nature of the healing process.

- Teach coping skills such as assertiveness, stress management and anger management or make appropriate referrals for her to receive such help.

Although the National Health Service (NHS) system means that often the victim does not have much say about the therapist/counsellor/nurse or psychiatrist to whom she is referred, it is important for effective healing that there is some kind of emotional match between the victim and the therapist. The victim needs to feel that the therapist or doctor is supportive and respectful towards her. For example, does she feel that she can talk about the trauma and her innermost feelings in safety? It may take several attempts to find a therapist who she feels able to trust, but without trust it is unlikely that any therapy or counselling will be effective.

\section{Resources to help the victim}

The resources or agencies listed below cannot guarantee consistency of approach between regions and even from one individual to another, but they make a good starting point.

- The police. Not many women report a rape to the police, but they can get the victim to a safe place and will know what resources are available within the local community to help her. They will know which hospitals will have specialised staff to help treat her, both physically and emotionally. Although at first the victim will feel intimidated and afraid of the rapist, she may well get angry at what he has done and that may be the time when she wished that she had reported it to the police. However, it is no easy thing to walk into a police station to report a rape and this is when other agencies may be of assistance.

- The general practitioner (GP). The family doctor can have an important role to play. The victim may report the rape to them, not just because they are concerned about their physical or mental health after the rape, but also because they cannot face going to the police. It would be helpful if the GP is aware of what facilities are available within the local area to help rape victims and also if they have a contact within the local police force so that reporting the crime can be made easier for the victim.

- The family planning or sexual health clinic. These clinics are open access and therefore offer anonymity. They may therefore feel a safe place to disclose the sexual abuse, especially if emergency contraception is required or there is concern about sexually transmitted infections (STIs). See FACT in this issue on 'Assisting and advising complainants of sexual assault in the family planning setting' (pages 127-131). 
- Rape crisis centres. These are located in many city centres and also offer counselling services. The umbrella organisation, the Rape Crisis Federation (RCF), acts as a referral service to individual women who are seeking advice and/or support around the issues of rape or sexual assault. For further information see the editorial on pages 120-122.

- Victim Support. This is a national charity that helps people cope with crime. For further information see the editorial on pages $122-123$.

Statements on funding and competing interests

Funding. None declared.

Competing interests. None declared.
Further reading

Ledray LE. Recovering from rape. New York, NY: Henry Holt and Company, 1994. Matsakis A. I can't get over it - a handbook for trauma survivors. Oakland, CA: New Harbinger Publications, 1996.

Author's Note. Throughout this article, because women are the primary victims of rape, the victim is referred to as she. This is not intended to exclude or discount men who have been the victims of such assaults.

Editor's Note. This editorial has been written from the perspective of a victim living in England or Wales. The legal experience may differ slightly in Scotland due to differences in Scots law. For further information see the editorial on pages $115-117$.

\section{The problem of rape and supporting victims}

Currently, the crimes of rape and sexual assault and the extent of their impact on victims appear to be the least understood by professionals and policymakers in comparison to other crimes. This is in contrast to policy on domestic violence, where there has been considerable change over the last 25 years in both institutional attitudes towards its 'relative acceptability', and in developing social policies and practices to support victims and deal with perpetrators. Whilst there are the beginnings of a sea change in relation to rape and criminal justice policy, 1,2 the idea of rape as a widespread social problem that inflicts considerable social harm still needs to be developed.

This lack of understanding about the problem of rape can be partially explained by the prevalence of myths and stereotypes, which Kelly ${ }^{3}$ defined as 'real' rape and 'real' victims of rape. Kelly suggests that there is a social 'template' of what constitutes 'real' rape. This involves rape by a stranger at night in a public place and the use of physical force or threats of physical force. Thus, the idea of 'real' rape contributes to negative institutional responses towards rape victims who do not fit this template but who, according to the research and victim surveys both in the UK and elsewhere, constitute the majority of rape victims. ${ }^{3,4}$ These studies indicate that stranger rape is less common than rape which is perpetrated by men who know their victims to a greater or less extent. Moreover, whilst there has been no UK study focusing on prevalence, a recent US prevalence study (cited in Kelly ${ }^{3}$ ) indicated that almost one in five women experienced rape or sexual assaults over a lifetime, 'a large proportion of victimisations occurred when the victim was aged under 18 years', and the majority of 'adult assaults (76\%) involved current or ex-partners or a date'.

\section{Forms of 'known' rape}

Forms of 'known' rape can range from women who meet the perpetrator through casual social contact (for example, in bars) and initial dates. This is officially known as acquaintance rape, although these forms are often all conflated and named in the press as 'date rapes'. 'Partner rape' is where the woman has an ongoing relationship with the perpetrator and this includes rape in marriage.

Younger women may be seen as particularly vulnerable to acquaintance rape, and may be specifically targeted by some perpetrators, ${ }^{5}$ whilst older women are most affected by partner rape. ${ }^{3,4}$ However, all these latter forms of rape attract greater social assumptions of victim blame and/or assumptions that victims are less affected by such experiences.

In relation to acquaintance rape there are examples of numerous common beliefs that are based on prevailing sexual double standards where women are seen to invite or deserve rape. ${ }^{5}$ Thus young women may be viewed as 'leading men on' and provoking men's 'uncontrollable' sexual impulses through their own social behaviour. They may also attract blame for consuming alcohol, which itself may be perceived as inviting rape, or by perpetrators as a means of facilitating rape. 'Drug-assisted' rape also falls into this category. Alternatively, such rapes can be trivialised by being viewed as miscommunication, rather than deliberate assaults, and can contribute to calls for treating such rapes as less serious in the criminal law. However, this is an approach that has been rejected by the Home Office in its recent review of the way the law regards sexual offences, ${ }^{1}$ where it states: 'It is harder to see how degrees of rape could be defined - when does a stranger become an acquaintance or a friend? The crime of rape is so serious that it needs to be considered in its totality rather than being constrained by any relationship between the parties ... there is neither justification nor robust grounds for grading rape into lesser or more serious offences.'

However, these kind of assumptions also contribute to some victims believing that their experiences are not 'real rape', and contribute to internalised self-blame. Partner and ex-partner rape may also be seen as not as serious as rape by a stranger, ${ }^{6}$ partly because once a woman has agreed to enter into a (long-term) relationship with a man it is assumed that she has consented to have sex with him on any occasion for all time. Research on partner rape shows it may often overlap with domestic violence and can be part of an 